\title{
Monetary Minute Currency - An Economic Value Setting Tool
}

\author{
Tomáš KALA \\ University of Hradec Králové, Hradec Králové, Czech Republic \\ tomas.kala@uhk.cz
}

\begin{abstract}
My design of the currency called "Monetary Minute" (in abbreviation $\mathrm{MMc}$ ) is based on postulating Time for a Value Commodity. The MMc is related to currently utilized currencies (like in $\$, €, £$, and others) via so called Time Based Money (TBM), which was defined as a fragment of the annual GDP, p.c. which corresponds to one minute, i.e. as GDP, p.c. divided by 525600 . MMc enables determination and comparison of apparent economical values in time units (Monetary Minutes) of the same/similar products or - in general - of all the economic entities expressed in different currencies. In the article, there are listed examples of application of the MMc (namely MM\$, MM£, MM€, MMK) for determination and comparison value of several products and commodities in the U.S., the German, the U.K., and the Czech Republic markets.
\end{abstract}

Keywords: Time, Economical Value, Time-Based Money, Monetary Minute Currency

\section{Introduction}

Economy is a wonderful discipline, which is of the utmost importance in all kinds of entrepreneurship, business, social activities of humankind, as well as in everyday life of people. However, Economy has a vexatious Achilles heel in a definition of the Value $[7,8,9]$. The role of the Value for evaluation of economic entities and processes in applied economy, entrepreneurship, business, everyday human activities, etc. has been played by money for ages - in its various forms [10, 16, 20, 22]. Namely, as a commodity physical money (shells, corrals, stones, pearls, gold, ...), representative money, paper money, banknotes/gold standard notes, coins, counterfeit money, fiat money, bank money, alternative/complementary money currencies based on time [21] (like so called Time Dollar, Time Credits, Service Credits [11), and "Minuto" time vouchers [5], and other forms[6]. Related Values of all of them have been based on negotiation/bargaining/settlement/ agreement/market situation/ economic and political power or position of the participants (individual merchants, firms, companies, countries, banks, etc.) [17].

The problem is even magnified by the fact, that modern money systems are prevailingly debt-based (enabling fractional reserve banking) instead of Value-based [20]. Further, the amount of money in current economies - and consequently its Value 
- is subjectively regulated by governments and central banks and/or by other monetary authorities on the basis of a declared monetary policy. These two aspects contribute/cause devastating financial crisis time to time e.g. [1, 2, 3, 4, 12, 13, 28]. Modern money is not tied to any "firm" or material background like gold used to serve for many years in the past.

In my previous works $[17,18]$, I have postulated Time as a Commodity for establishment/measurement/ evaluating a value of economic entities and processes. Reasons for this are obvious:

- everybody has at disposal just 24 hours or 1440 minutes, or 86400 seconds total in a day; this feature can be a firm foundation, or "commodity", for a valuable timesteady money system, as an hour is 3600 seconds today, and will be the tomorrow and in future;

- time (namely the human life time) is the most precious value in the world, which is not a subject of inflation;

- time (especially the labor time) can be supposed as a specific commodity whose value is extraordinary per se;

- an amount of the time of a country/state is in a direct correlation with an increase or decrease of its population;

- this feature can be used as a very useful measure or as a natural regulator for the money supply of a currency of the countries or states;

- the amount of the time total is at disposal to countries/states (or broadly speaking mankind) for managing all the emerging challenges, possibilities, opportunities, threads, and other circumstances coupled with the increasing or decreasing number of population;

- the quality of the time-based currency could reflect/differ/measure a quality of managerial processes, effectivity, efficiency, productivity, as well as an influence of geographical, demographical, natural, political, social, and others factors in different places and historical on real economic processes.

In my works $[17,18,19]$, I have defined a new currency called a "TBM" (for TimeBased Money), as a value of the GDP per capita divided by the number of minutes per year (i.e. 525600) [19].

I have tested the TBM values in the U.S. and the Czech economies, and later on in the Slovak, Polish, and Hungary economies, for span of 2011-2015 years, too. I have revealed - among others interesting features - that the TBM values expressed in relevant national currencies exhibited systematic increase in their values, however, the TBM values expressed in U.S. \$ or in Euro showed erratic development in the span of time studied without any objective reasons $[17,18,19]$.

In the current evaluation study, I have focused on the comparison of the living costs and/or incomes evaluated in so called Monetary Minute currencies (in abbreviation $\mathrm{MMc}$ ), which were related to the currently utilized currencies (like in $\$, €, £$, and others) via the above mentioned TMB. 


\section{Methods Used}

This evaluation study is based on the method of qualitative analysis of secondary data and information available on the function of money - especially of the Time-Based Money in real economy. I have designed a new currency called a "TBM" (for TimeBased Money), (defined as a value of the GDP per capita divided by the number of minutes per year (i.e. by 525600) [17].

I calculated TBM values for the U.S., German, U.K., and Czech economies, respectively, in 2016 (the values of the TBM are presented in the Table 1). I took the data from the Czech National Bank [29], the Czech Statistical Office [30], the portal for statistics Statista [27], the D-Statis [15], the World Bank [32], the United Nations World Population Prospects [33], and the U.S. Census Bureau [31].

I used values of living costs and incomes in the relevant countries in the year 2016 from NUMBEO [23, 24, 25, 26]. I divided the individual items of the living costs by the relevant TBM of each of the countries; thus, I had obtained the living costs and incomes evaluated in MMc (see Table 2 and Figure 1). I re-normalized the values by the Average Monthly Disposable Salary - Expressed in Monetary Minutes - in the United States in 2016, i.e. the individual items of living costs were multiplied by the ratios: 27408/11389 for the Czech Republic 27408/31097 for the United Kingdom, and 27408/31111 for the Germany, respectively (see Table 3 and Figure 2).

\section{Results}

In the Table 1, there are given values of the GDP per capita and the TBM in current currencies of the Unites States, United Kingdom, Germany and the Czech Republic, respectively, in 2016. The individual values of the GDP per capita, and consequently of the TBM expressed in current currencies used in individual states differ considerably as the currencies differ in their nominal values.

Table 1. Values of the GDP p.c. and the TBM in Current Currencies of the United States, United Kingdom, Germany and the Czech Republic in 2016, source: own based on [15, 27, 29, $30,31,32,33]$.

\begin{tabular}{lrr}
\hline & GDP, p.c. & TBM \\
\hline United States & $55837 \$$ & 0.10623 TB $\$$ \\
United Kingdom & $29898 £$ & 0.05688 TB£ \\
Germany & $36906 €$ & 0.07022 TB€ \\
Czech Republic & $1007643 \mathrm{CZK}$ & $1.91713 \mathrm{TBK}$ \\
\hline
\end{tabular}

In the Table 2, there is given a list of several food staffs and also salaries expressed in the local currencies and in Monetary Minutes values in the individual states. The values of individual items of the living costs expressed in MMc are systematically lower in the Czech Republic than in the other countries, because the related values in MMc are lower. The phenomenon can be observed in the Figure 1, too. Seemingly, it could be 
understood as the living costs are most advantageous (lower) in the Czech Republic in comparison with other countries under discussion. However, taking into account the level of allocated Average Monthly Disposable Salary (Net After Tax) expressed in MMC, which is about 2.4 times lower than the allocated amount of MMc Monthly in the United States, the overall picture changes considerably, as it is shown in the Table 3 and in the Figure 2.

Table 2. List of Several Food Staffs Prices and Average Monthly Disposable Salaries Expressed in Local Currencies and in Monetary Minute Values in 2016, source: own based on $[15,23,24,25,26,27,29,30,31,32,33]$.

\begin{tabular}{|c|c|c|c|c|c|c|c|c|}
\hline & \multicolumn{2}{|c|}{ Czech Republic } & \multicolumn{2}{|c|}{ Germany } & \multicolumn{2}{|c|}{ U.K. } & \multicolumn{2}{|c|}{ U.S. } \\
\hline & $\mathrm{CZK}$ & MMK & EUR & MM€ & $\mathrm{BP}$ & MM£ & USD & MM \$ \\
\hline $\begin{array}{l}\text { Meal for } 2 \text { People, Mid-range } \\
\text { Restaurant, Three-course }\end{array}$ & 500.00 & 261 & 45.00 & 641 & 50.00 & 879 & 50.00 & 471 \\
\hline Meal, Inexpensive Restaurant & 115.00 & 60 & 10.00 & 142 & 12.00 & 211 & 12.95 & 122 \\
\hline Bottle of Wine (Mid-Range) & 100.00 & 52 & 5.00 & 71 & 7.00 & 123 & 12.00 & 113 \\
\hline $\begin{array}{l}\text { Beef Round }(1 \mathrm{~kg}) \text { (or } \\
\text { Equivalent Back Leg Red } \\
\text { Meat) }\end{array}$ & 215.86 & 113 & 9.58 & 136 & 7.76 & 136 & 11.58 & 109 \\
\hline Local Cheese (1kg) & 172.54 & 90 & 6.89 & 98 & 5.59 & 98 & 10.77 & 101 \\
\hline $\begin{array}{l}\text { Chicken Breasts (Boneless, } \\
\text { Skinless), (1 kg) }\end{array}$ & 139.88 & 73 & 7.29 & 104 & 6.00 & 105 & 8.55 & 80 \\
\hline $\begin{array}{l}\text { McMeal at McDonalds (or } \\
\text { Equivalent Combo Meal) }\end{array}$ & 120.00 & 63 & 7.00 & 100 & 5.00 & 88 & 7.00 & 66 \\
\hline Pack of Cigarettes (Marlboro) & 95.00 & 50 & 6.00 & 85 & 9.00 & 158 & 6.50 & 61 \\
\hline $\begin{array}{l}\text { Imported Beer ( } 0.33 \text { liter } \\
\text { bottle) }\end{array}$ & 35.00 & 18 & 3.00 & 43 & 3.79 & 67 & 5.00 & 47 \\
\hline Apples $(1 \mathrm{~kg})$ & 27.04 & 14 & 1.99 & 28 & 1.81 & 32 & 4.23 & 40 \\
\hline $\begin{array}{l}\text { Domestic Beer ( } 0.5 \text { liter } \\
\text { draught })\end{array}$ & 30.00 & 16 & 3.50 & 50 & 3.50 & 62 & 4.00 & 38 \\
\hline $\begin{array}{l}\text { Average Monthly Disposable } \\
\text { Salary (Net After Tax) }\end{array}$ & 21835 & 11389 & 2184 & 31097 & 1770 & 31111 & 2912 & 7408 \\
\hline
\end{tabular}




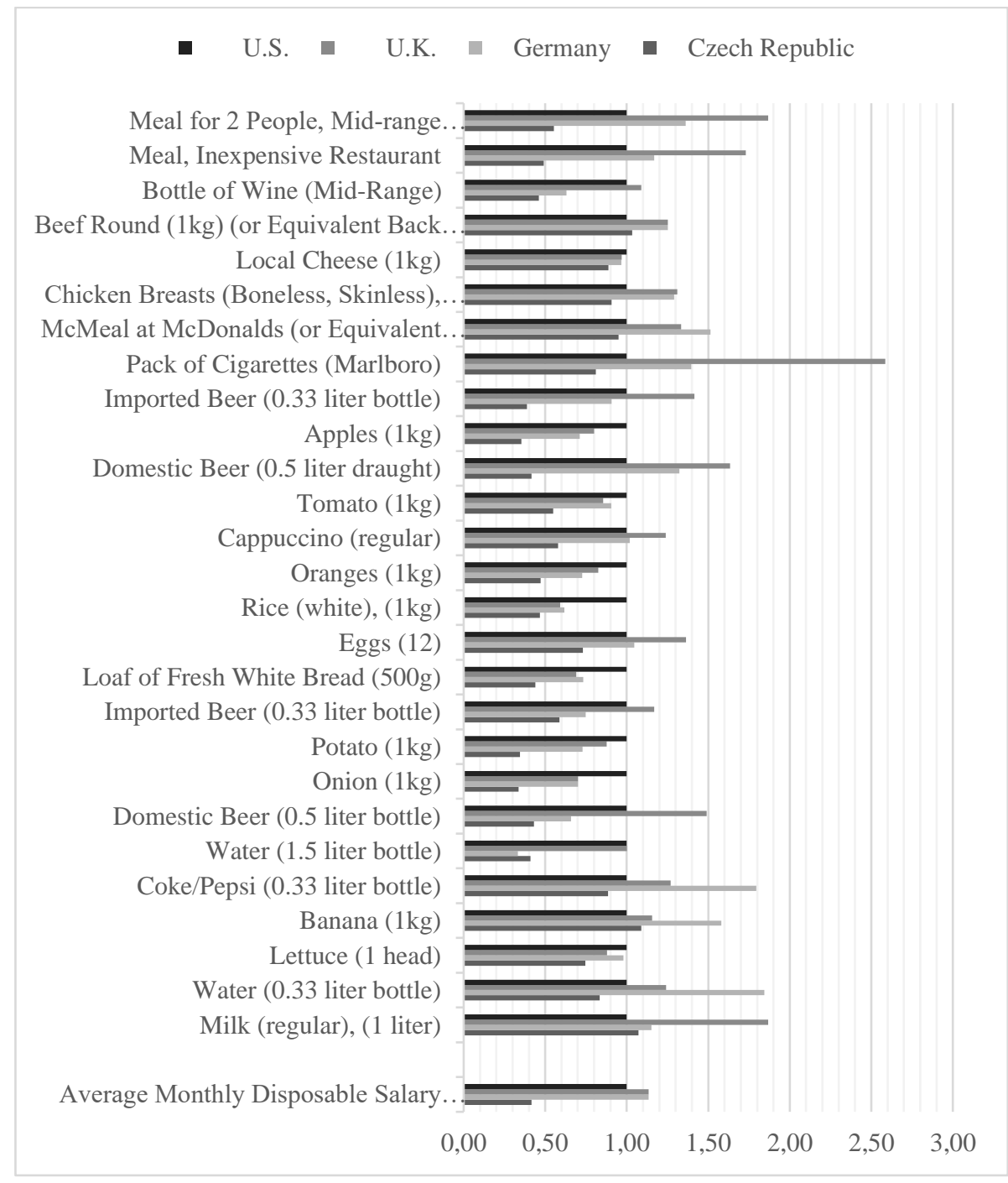

Figure 1. Ratios of the Several Food Staff Prices and Average Monthly Disposable Salaries Related to the Ones in the U.S. in 2016, source: own based on [15, 27, 29, 30, 31, 32, 33].

In the Table 3, there is given the same list of several food staffs in Monetary Minutes after re-normalizing them by the average monthly disposable salaries (as high as 27408 MM\$) in the United States in 2016. These relations among the re-normalized MMC values in individual states changed significantly when compared with related values given in the Table 2 and in the Figure 1 with relation to the U.S. market environment. Namely in the Czech Republic, the re-normalized MMK values of the selected food staffs are considerably higher than in the U.S. and in Germany. 
Table 3. List of Several Food Staffs Prices in MMc Values after Re-Normalizing them by the Average Monthly Disposable Salaries (Expressed in Monetary Minutes) in the United States in 2016, source: own based on [15, 27, 29, 30, 31, 32, 33].

\begin{tabular}{lccccc}
\hline & & & & \\
& MMCZK & MM€ & MM£ & MM\$ \\
& in Czech & in & in the & in the \\
& Republic & Germany & U.K. & U.S. \\
\hline Meal for 2 People, Mid-range Restaurant, Three-course & 628 & 565 & 774 & 471 \\
Meal, Inexpensive Restaurant & 144 & 126 & 186 & 122 \\
Bottle of Wine (Mid-Range) & 126 & 63 & 108 & 113 \\
Beef Round (1kg) (or Equivalent Back Leg Red Meat) & 271 & 120 & 120 & 109 \\
Local Cheese (1kg) & 217 & 86 & 87 & 101 \\
Chicken Breasts (Boneless, Skinless), (1kg) & 176 & 92 & 93 & 80 \\
McMeal at McDonalds (or Equivalent Combo Meal) & 151 & 88 & 77 & 66 \\
Pack of Cigarettes (Marlboro) & 119 & 75 & 139 & 61 \\
Imported Beer (0.33 liter bottle) & 44 & 38 & 59 & 47 \\
Apples (1kg) & 34 & 25 & 28 & 40 \\
Domestic Beer (0.5 liter draught) & 38 & 44 & 54 & 38 \\
\hline
\end{tabular}




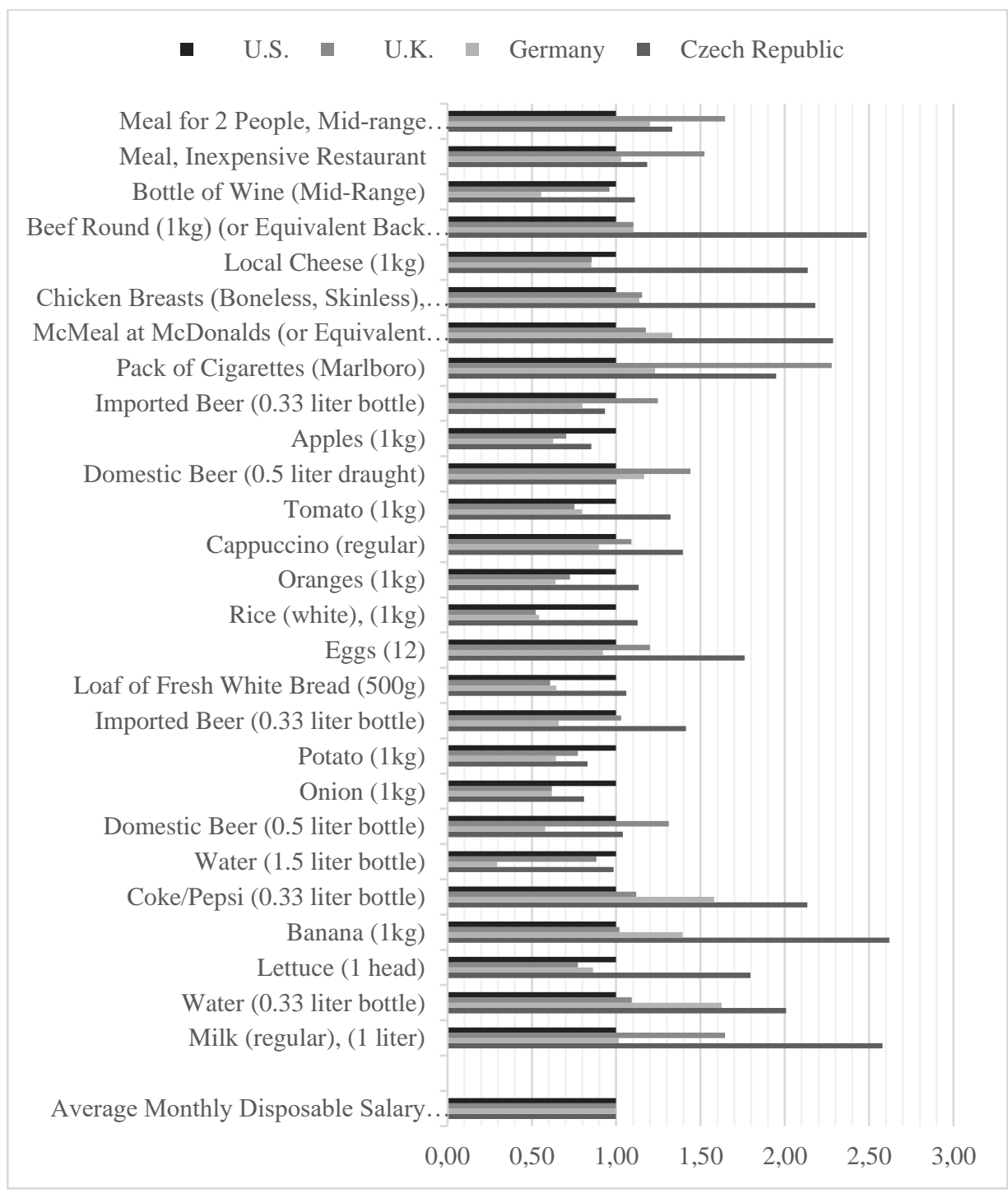

Figure 2. Ratios of Several Food Staffs Prices after Re-Normalizing them by the Average Monthly Disposable Salaries in the United States in 2016, source: own based on [15, 27, 29, 30, $31,32,33]$.

In the Table 4, there is given a list of several commodity prices in the Czech market, at randomly selected day April 26th 2017 (Collective of authors, 2017H). They were expressed in the U.S. dollars, Czech currency (CZK), EUR, Great Britain Pounds, and also in relevant Monetary Minute values, respectively. It can be seen, that prices of individual commodities expressed in individual currencies are very different and 
confusing. Meanwhile, the ones expressed in the related Monetary Minute currencies enable to compare and testify their values in the Czech market in relation to the currency market in Czech Republic. A noticeable overvaluation of the U.S. dollar against the values of other currencies in the Czech Republic at that time can be derived from these MMC values.

Table 4. List of Several Commodity Prices in the Czech Market Expressed in US\$, CZK, $€, £$ Currencies, and in related MonMin Values (at April 25th 2017), , source: own based on [14, 29].

\begin{tabular}{|c|c|c|c|c|c|c|c|c|c|}
\hline \multirow{3}{*}{ Commodity } & \multirow{3}{*}{ Unit } & \multicolumn{4}{|c|}{ Values in Traditional } & \multicolumn{4}{|c|}{ Values in MonMin } \\
\hline & & Currenci & & & & Curren & cies & & \\
\hline & & US\$ & $\mathrm{CZK}$ & $€$ & $£$ & MM\$ & MMCZK & MM€ & MM£ \\
\hline Electricity & $1 \mathrm{MWh}$ & 31.854 & 783.02 & 29.25 & 24.837 & 300 & 408 & 417 & 437 \\
\hline Crude Oil Brent & 1 Barel & 52.30 & 1286.53 & 48.02 & 40.778 & 492 & 671 & 684 & 717 \\
\hline Natural Gas & MMBtu & 3.5 & 74.969 & 2.80 & 2.377 & 29 & 39 & 40 & 42 \\
\hline Gold & $1 \mathrm{oz}$ & 1265 & 31093.7 & 1161.51 & 986.35 & 11908 & 16219 & 16541 & 17340 \\
\hline Wheat & 100 Bushl & 409.25 & 10059.37 & 375.77 & 319.1 & 3852 & 5247 & 5351 & 5610 \\
\hline Cotton & 100 Pound & 79.36 & 1950.67 & 72.867 & 61,878 & 747 & 1017 & 1038 & 1088 \\
\hline Currency Ratio & $\mathrm{CZK}$ & 24.58 & 1 & 26.77 & 31.524 & & & & \\
\hline TBM & & 0.10623 & 1.917129 & 0.070218 & 0.056883 & & & & \\
\hline
\end{tabular}

\section{Conclusions}

This evaluation study is a part of my testing the idea of using Time as a prospective base/commodity for a new money system, which would be objective, predictable, dynamically evolving, and readily introduced in economy, business and everyday life.

I have focused on the comparison of the living costs and/or incomes evaluated in so called Monetary Minute currencies (in abbreviation MMc) in this article, consequently to my previous works [19], in which I defined a new currency called a "TBM" (for Time-Based Money) as a value of the GDP per capita divided by the number of minutes per year (i.e. 525600). The MMc were related to the currently utilized currencies (like in $\$, €, £$, and others) via the above mentioned TMB. 
The results of the current study show, that MMc enable comparison of apparent values of the same/similar products or - generally - all economic entities expressed in different currencies, and to reveal disparities among them. They revealed not just the differences in prices of selected food staffs but also the differences in affordability of the products taking into account the average monthly disposable salaries in different countries on the "homologized" Monetary Minute base.

The current nominal value of a specific economic entity expressed in Monetary Minutes, i.e. MM\$, MM£, MM€, etc. differs in relation on which current money currency system - USD, GBP, EUR, etc. - is used, respectively.

Thus, the results show that the MMC can be useful for the comparison and testing values of different currencies on the currency markets and revealing disparities (overvaluations/undervaluation) among the values of currencies on the specific market.

Taking into account the results of the previous work [17, 18], in which the Time Based Money lit the light on the distortion effects of central banks currency politics on real economies development, I state that the TBM and MMc are prospective tools for tracing, measuring, and analyzing wide spectrum of value transformations in real economy, including production costs/efficiency diversities in different countries or regions, and different historical eras in a more objective way, than the current spectrum of currencies worldwide enable.

The quantitative accuracy and reliability of the results given in the study are limited by the accuracy and reliability of the figures available and the time of its creation. Nevertheless, the quality of the fundamental finding, i.e.: the currency MonMin can serve as a useful and practical tool for the Value determination/measurement of any economical entities (either elements and/or processes) is undeniable.

Note: I do not insist on the only term/name/title "MMc" for the currency called "Monetary Minute". The abbreviations such as TMc (for the "Time Money Currency") could be better for practical use (especially, when relating to the specific traditionally used money (like "Time Money Dollar" - TM\$ or "Time Dollar" - T\$, "Time Money Pond" - TM£ or "Time Pound"- T£, "Time Money EUR" - TM€ or "Time EUR" - T€, etc.)).

Acknowledgements. The author of the contribution is obliged to express deep thanks to Prof. Ing. Ladislav Hájek, CSc form the Faculty of Informatics and Management of the University of Hradec Kralove for his valuable discussions and advice which considerably improved the quality of the contribution.

The author is grateful Dr. Frank Lefley PhD, Mphil, MSc, FRSA from the Royal Holloway, University of London, United Kingdom, the Research Fellow of the University of Hradec Kralove, for encouraging him to publish this work. 


\section{References}

1. Bernanke, B.S.: Four Questions about the Financial Crisis, Lecture at Morehouse College, Atlanta, Georgia, Board of Governors of the Federal Reserve System, 14. April, (2009). http://www.federalreserve.gov/newsevents/speech/bernanke20090414a.htm, last accessed 2017/06/27.

2. Classens, S. and Kose, M.A.: Financial Crises: Explanations, Types, and Implications, IMF Working Paper WP/13/28, International Monetary Fund (2013). http://www.imf.org/external/pubs/ft/wp/2013/wp1328.pdf , last accessed 2017/06/27.

3. Collective of authors: Angelides Commission Conclusion of the Financial Crisis Inquiry Commission, January (2011). http://web.archive.org/web/20110304020317/http://c0182732.cdn1.cloudfiles.rackspaceclo ud.com/fcic_final_report_conclusions.pdf , last accessed 2017/06/27.

4. Collective of authors: Financial crisis of 2007-08, http://en.wikipedia.org/wiki/Financial_crisis_of_2007\%E2\%80\%9308, last accessed 2017/06/27.

5. Collective of authors: Minuto Currency, http://occupyconcepts.org/wiki/Minuto_Currency, last accessed 2014/11/13.

6. Collective of authors: Occupy Money, http://occupyconcepts.org/wiki/Occupy_Money, last accessed 2014/11/13.

7. Collective of authors: Value (economics), http://en.wikipedia.org/wiki/Value_(economics), last accessed 2017/06/27.

8. Collective of authors: Labor theory of value, http://en.wikipedia.org/wiki/Labor_theory_of_value, last accessed 2017/06/27.

9. Collective of authors: Economic growth, Wikipedia , http://en.wikipedia.org/wiki/Economic_growth, last accessed 2017/06/27.

10. Collective of authors: Quantity theory of money, Wikipedia, http://en.wikipedia.org/wiki/Quantity_theory_of_money, last accessed 2017/06/27.

11. Collective of authors: Time-based currency, http://en.wikipedia.org/wiki/Timebased_currency, last accessed 2017/06/27.

12. Collective of authors: Financial Crisis Inquiry Commission, Wikipedia, http://en.wikipedia.org/wiki/Financial_Crisis_Inquiry_Commission, last accessed 2017/06/27.

13. Collective of authors: Fractional-reserve banking,

14. http://en.wikipedia.org/wiki/Fractional-reserve_banking, last accessed 2017/06/27.

15. Collective of Authors: Kurzycz, Komodity a deriváty - kurzy komodit, potravin, obilnin, surovin, kovi̊ a energii, Kurzy futures na komodity podle druhu ze dne 25.4.2017, http://www.kurzy.cz/komodity/ceny-energie-potravin-surovin-kovu/ , last accessed 2017/04/26.

16. D-Statis: Statistisches Bundesamt, 2016.

17. https://www.destatis.de/EN/FactsFigures/NationalEconomyEnvironment/NationalAccount s/DomesticProduct/Tables/Q_GDP.html, last accessed 2017/03/30.

18. Friedman, M.: Money, Encyclopaedia Britannica, https://www.britannica.com/topic/money, last accessed 2017/06/27.

19. Kala, T.: Management \& Financial and Economic Crisis 2007-2008, Conference on Economic Development and Management of Regions, Hradec Economic Days (HED) 2014, Hradec Kralove 2014, Gaudeamus Hradec Kralove, (2014). ISBN 978-80-7435-366-6.

20. Kala, T.: Time-Based Money System: Its Use in the U.S.A. and the Czech Economies, 2016 Advancement on Informatics, Business and Management International Conference 
(ADIBUM), September 20 - 22, 2016, University of Hradec Kralove, Czech Republic, Journal of Engineering and Applied Sciences (Medwell Journals) Special Issue. ISSN 1816949x (Print) ISSN 1818-7803 (in Print).

21. Kala, T.: Time-Based Money in V4 Economies, Hradec Economic Days (HED) 2017, Hradec Kralove 2017, Gaudeamus Hradec Kralove, (2017). ISSN 2464-6032 (Print), ISSN 2464-6040 (Online).

22. Kortsch, U.: Monetary Plan Overview, Monetary Trust Initiative. https://wiki.p2pfoundation.net/Monetary_Trust_Initiative, last accessed 2017/06/27.

23. Mishkin, F.S.: The Economics of Money, Banking, and Financial Markets (Alternate Edition), Boston, Addison Wesley. (2007), p. 8. ISBN 0-321-42177-9.

24. Ng, S. and Wright, J.H.: Facts and Challenges from the Great Recession for Forecasting and Macroeconomic Modeling, Journal of Economic Literature 51(4), 1120-1154. http://dx.doi.org/10.1257/jel.51.4.1120

25. NUMBEO: Costs

of $\quad$ Living,

https://www.numbeo.com/common/form.jsp?country=United+States\&returnUrl=\%2Fcostof-living\%2Fcountry_result.jsp\%3Fcountry\%3DUnited\%2BStates, last accessed 2017/03/30.

26. NUMBEO: Costs of Living,

https://www.numbeo.com/common/form.jsp?country=United+Kingdom\&returnUrl=\%2Fc ost-of-living\%2Fcountry_result.jsp\%3Fcountry\%3DUnited\%2BKingdom, last accessed 2017/03/30

27. NUMBEO: Costs of Living, https://www.numbeo.com/common/form.jsp?country=Germany\&returnUrl=\%2Fcost-ofliving\%2Fcountry_result.jsp\%3Fcountry\%3DGermany, last accessed 2017/03/30.

28. NUMBEO: Costs of Living, https://www.numbeo.com/common/form.jsp?country=Czech+Republic\&returnUrl=\%2Fco st-of-living\%2Fcountry_result.jsp\%3Fcountry\%3DCzech\%2BRepublic, last accessed 2017/03/30

29. Statista: Gross domestic product (GDP) per capita of the United Kingdom (UK) in current prices from 2010 to 2020 (in U.S. dollars), https://www.statista.com/statistics/263600/gross-domestic-product-gdp-per-capita-in-theunited-kingdom/, last accessed 2017/03/30.

30. The Board of the Governors of the Federal Reserve System: Credit and Liquidity Programs and the Balance Sheet, http://www.federalreserve.gov/monetarypolicy/bst.htm, last accessed 2016/07/25.

31. The Czech National Bank: http://www.akcie.cz/kurzovni-listek/kurzymen?gclid=CPzF9ZjnhbMCFZHRzAodzkgACQ , last accessed 2016/07/26.

32. The Czech Statistical Office: Database of National Accounts, GDP by the Production Approach, http://apl.czso.cz/pll/rocenka/rocenkavyber.makroek_prod_en , last accessed 2016/07/26.

33. The U.S. Census Bureau: http://www.census.gov/popclock/ (22.07.2016).

34. World Bank: International Comparison Program database, http://data.worldbank.org/indicator/NY.GDP.PCAP.PP.CD?order=wbapi_data_value_201 4+wbapi_data_value+wbapi_data_value-last\&sort=desc, last accessed 2016/07/17.

35. World Population Prospects: https://esa.un.org/unpd/wpp/Download/Standard/Population/, last accessed 2017/03/30. 